\title{
Badania satysfakcii użytkowników w bibliotekach publicznych województwa dolnośląskiego
}

DOI: http://dx.doi.org/10.12775/TSB.2017.005

STRESZCZENIE: W 44 bibliotekach publicznych województwa dolnośląskiego (biblioteka wojewódzka, biblioteki miejskie, miejsko-wiejskie, wiejskie) przeprowadzono badania satysfakcji użytkowników przy użyciu ujednoliconej ankiety i procedury badawczej. Badania zostały zorganizowane i koordynowane przez członków Zespołu SBP ds. badania efektywności bibliotek. Wynikiem badań było wyznaczenie wskaźnika „Satysfakcji Użytkowników”, który wraz z innymi wskaźnikami funkcjonalności, opracowanymi w ramach projektu „Analiza Funkcjonowania Bibliotek", stanowi system kompleksowego pomiaru efektywności biblioteki.

SŁowA KLUCzowe: badania efektywności, badania ankietowe, biblioteki publiczne, wskaźnik „Satysfakcji Użytkowników”. 


\section{"Analiza Funkcjonowania Bibliotek" i wskaźnik "Satysfakcii Użytkowników"}

$\mathrm{O}$ d 2010 r. w ramach Stowarzyszenia Bibliotekarzy Polskich [dalej: SBP] realizowany jest ogólnopolski projekt „Analiza Funkcjonowania Bibliotek" [daje: AFB], którego celem jest wypracowanie, wdrożenie, a następnie upowszechnienie systemu analizy funkcjonalności bibliotek publicznych, pedagogicznych i naukowych, wykorzystującego jednolite metody i narzędzia służące do systematycznej oceny działalności bibliotek. Jednostki biorące udział w projekcie mają dostęp do bazy umożliwiającej gromadzenie, archiwizowanie oraz automatyczne generowanie wskaźników efektywności, które następnie można porównywać z uśrednionymi wartościami dla danej grupy instytucji.

Dzięki gromadzonym danym statystycznym, a przede wszystkim wyliczonym na ich podstawie wskaźnikom funkcjonalności, biblioteki mogą mierzyć efektywność, wydajność i jakość swoich działań oraz dążyć do wypracowania wspólnych standardów funkcjonowania.

Potrzeba kompleksowego badania efektywności bibliotek skłoniła Zespół ds. badania efektywności bibliotek [dalej: Zespół], aby do zestawu wskaźników obrazujących funkcjonowanie biblioteki w zakresie różnego typu usług i zasobów bibliotecznych (zbiory, infrastruktura, pracownicy, finanse) dołączyć wskaźnik prezentujący ocenę pracy danej instytucji z punktu widzenia odbiorców usług bibliotecznych, czyli wskaźnik „Satysfakcji Użytkowników”. Został on zdefiniowany zgodnie z normą PN-ISO 11620:2012 Informacja i dokumentacja - Wskaźniki funkcjonalności bibliotek. Spośród wszystkich wskaźników funkcjonalności bibliotek jedynie wskaźnik „Satysfakcji Użytkowników” - ze względu na swój syntetyczny charakter - stanowi kompleksową miarę całości usług bibliotecznych, czyli efektu końcowego działalności biblioteki z punktu widzenia jej użytkownika.

Warto zwrócić uwagę na znaczenie i powiązania wskaźników „Satysfakcji Użytkowników" (globalnego i szczegółowych) z innymi wskaźnikami

1 Kluczowym wskaźnikiem jest globalny wskaźnik „Satysfakcji Użytkowników”, obrazujący ocenę całokształtu pracy biblioteki z punktu widzenia użytkowników. Możliwe jest także wyznaczenie szczegółowych wskaźników „Satysfakcji Użytkowników”, które dotyczą oceny poszczególnych zasobów, usług, pracowników, kwestii organizacyjnych. 
funkcjonalności. Większość z nich pozostaje w relacji ze wskaźnikami satysfakcji, ale stopień zależności jest dość zróżnicowany. Dlatego interpretacja wielu wskaźników funkcjonalności powinna być powiązana z analizą odnoszącą się do wskaźnika satysfakcji stanowiącego ocenę biblioteki jako całości (globalny wskaźnik „Satysfakcji Użytkowników”) lub do szczegółowych wskaźników, dotyczących oceny poszczególnych usług, zasobów i form pracy. Większość wskaźników funkcjonalności mierzy nakłady po stronie bibliotek, natomiast wskaźniki satysfakcji mają za zadanie ocenę efektów realizowanych usług bibliotecznych z perspektywy użytkowników. Zestawienie wskaźników funkcjonalności ze wskaźnikiem satysfakcji (globalnym lub szczegółowymi) dostarcza informacji, czy wzrost/spadek nakładów personalnych, finansowych, rzeczowych w danym obszarze działalności bibliotecznej skutkuje wzrostem/spadkiem stopnia satysfakcji użytkowników w analizowanym okresie.

Przykładowo, możliwe są analizy wskaźników funkcjonalności dotyczących liczby zbiorów, nabytków czy wydatków na poszczególne typy zbiorów w kontekście ich oceny przez użytkowników, czy też wskaźników związanych z organizacją pracy biblioteki (np. liczba godzin otwarcia, dostępność stanowisk komputerowych, powierzchnia biblioteki) z oceną tych obszarów dokonaną przez uczestników badań ankietowych. Zestawienie wskaźników określających udział użytkowników w szkoleniach lub wydarzeniach kulturalnych z ocenami osób korzystających z tych usług może dostarczyć wielu ciekawych informacji na temat jakości proponowanych imprez. Kompleksowa analiza wszystkich wskaźników tworzy system całościowego pomiaru funkcjonowania biblioteki.

Dołączenie wskaźnika „Satysfakcji Użytkowników” do listy wskaźników efektywności w projekcie AFB wymagało przygotowania wspólnej metodologii badań dla wszystkich typów bibliotek: publicznych, pedagogicznych i naukowych. Na podstawie zaleceń Normy ISO 11620 Zespół ustalił, że wskaźniki uzyskiwane są na podstawie badań ankietowych prowadzonych wśród aktywnych użytkowników (powyżej 13 roku życia) danej biblioteki (zarówno biblioteki głównej, jak i filii bibliotecznych). Opracowana w tym celu ankieta zawiera trzy pytania zamknięte oraz metryczkę. Pytanie pierwsze dotyczy sposobów korzystania z biblioteki. Respondent może wskazać spośród 11 propozycji dowolną liczbę celów odwiedzin, które najczęściej realizuje w bibliotece. Pytanie drugie obejmuje ogólną ocenę funkcjonowania biblioteki w skali pięciostopniowej, tj. 
od 1 (ocena najniższa) do 5 (ocena najwyższa). Na podstawie tego pytania wyliczany jest globalny wskaźnik „Satysfakcji Użytkowników” jako średnia arytmetyczna ocen uzyskanych od respondentów. W pytaniu trzecim zaproponowano ocenę 14 elementów odnoszących się do zasobów, usług, wyposażenia i form pracy również według skali pięciostopniowej 1-5 (jak w pytaniu drugim) oraz dodano wariant odpowiedzi ND - nie dotyczy (możliwy do wskazania, gdy użytkownik nie korzysta lub nie zna danej usługi). Na podstawie tego pytania wyliczane są szczegółowe wskaźniki satysfakcji. Ostatnia grupa danych identyfikowanych w kwestionariuszu zawarta jest w metryczce i dotyczy wieku, płci, statusu użytkowników oraz częstości korzystania przez nich z usług biblioteki. Metryczka jest jedynym elementem różnicującym kwestionariusz w zależności od typu biblioteki.

Ponadto Zespół zarekomendował wykorzystanie w badaniach kwotowego doboru próby badawczej, który - jak wykazały badania pilotażowe - znacznie lepiej niż dobór losowy sprawdził się w środowisku użytkowników bibliotek.

Przeprowadzenie badań za pomocą zestandaryzowanego narzędzia i jednolitej metody umożliwia porównywanie wyników w ramach jednej biblioteki dla różnych odcinków czasu (jeśli badania prowadzone są systematycznie co 2-3 lata) lub w obrębie danych grup bibliotek poprzez porównanie do średnich wartości wskaźników. Standardowe badania dają możliwość uzyskania wiarygodnych danych, zwiększają zaufanie $\mathrm{w}$ procesie pomiaru i zmniejszają ryzyko popełniania błędów.

Wszelkie materiały zawierające szczegółowy opis procedury badawczej, analizy uzyskanych danych, instrukcje i narzędzia przygotowane przez Zespół, niezbędne do prawidłowego przeprowadzenia badania satysfakcji w bibliotece, dostępne są na stronie http://afb.sbp.pl/. Materiały są ogólnodostępne, może z nich skorzystać każda biblioteka, bez względu na to, czy uczestniczy w projekcie AFB, czy nie.

\section{Badania satysfakcii użytkowników w bibliotekach województwa dolnoślq̨skiego}

Jednym z celów projektu AFB jest rozpropagowanie w środowisku bibliotekarskim badań satysfakcji użytkowników oraz zachęcenie jak największej grupy bibliotek do ich realizacji. W związku z tym jedno z zadań 
projektu dotyczyło przeprowadzenia badań w bibliotekach województwa dolnośląskiego. Przedsięwzięcie to było realizowane w okresie od stycznia do maja 2016 r. Badania były przygotowane i koordynowane przez członków Zespołu ds. badania efektywności bibliotek. Zespół miał możliwość sprawdzenia zaprojektowanej metody i narzędzia badawczego, a także identyfikacji problemów pojawiających się w czasie badania oraz sposobów analizy zebranych danych. Ważnym celem było również uświadomienie bibliotekarzom korzyści płynących z tego typu badań. Zespół rozpoczął prace od wyboru bibliotek, przygotowania materiałów szkoleniowych, opracowania planu badań i harmonogramu ich realizacji.

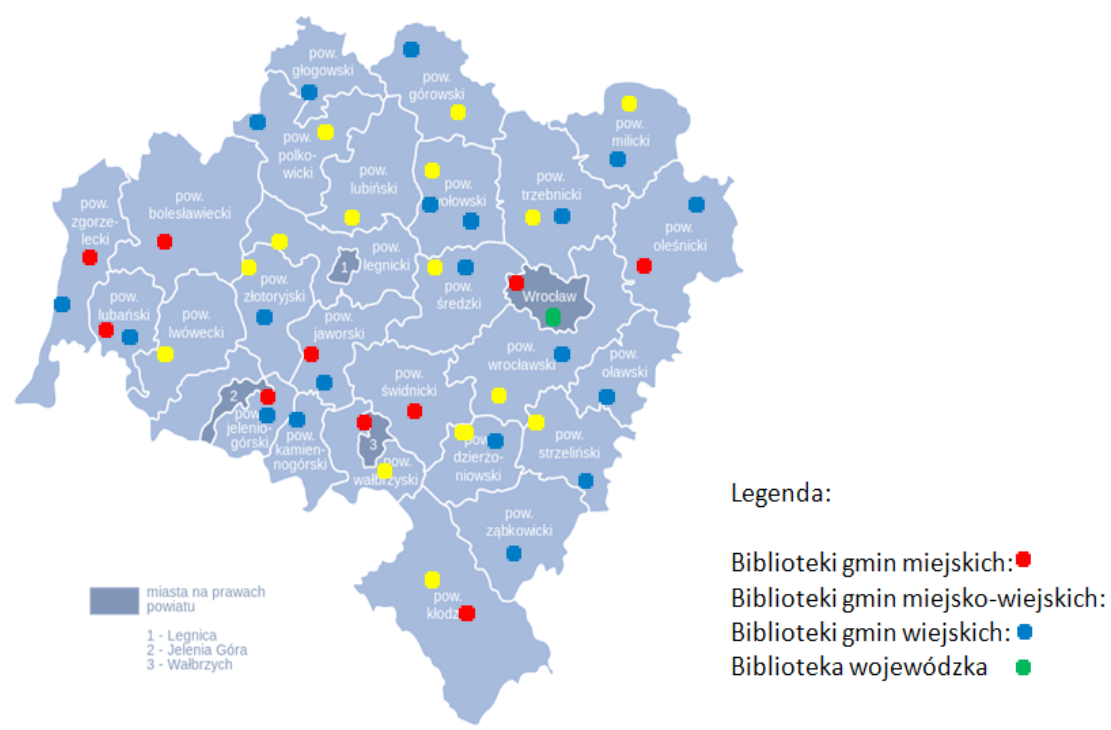

Rysunek 1. Lokalizacja bibliotek biorących udział w badaniach satysfakcji użytkowników

Źródło: opracowanie własne.

Spośród 171 bibliotek województwa dolnośląskiego należało wybrać grupę, która zostanie objęta badaniem. Biorąc pod uwagę, iż badania miał koordynować trzyosobowy Zespół, oraz ograniczenia narzędzia, które miało zostać wykorzystane do przeprowadzenia szkoleń online (platforma Clickmeeting), liczba bibliotek uczestniczących w badaniu 
nie mogła być większa niż 50 jednostek. W województwie dolnośląskim występuje: 36 bibliotek miejskich, 55 miejsko-wiejskich oraz 79 wiejskich, co daje proporcję 1:1, 5:2. Zachowując te proporcje, zdecydowano, iż badaniem zostanie objętych: 10 bibliotek miejskich, 15 miejsko-wiejskich i 20 wiejskich +1 biblioteka wojewódzka, czyli w sumie 46 instytucji, co stanowi ok. 27\% ogółu bibliotek publicznych w tym województwie. Następnie z każdej wyznaczonej wg typu grupy wylosowano określoną liczbę bibliotek. Na rys. 1. zostały zaznaczone biblioteki wytypowane do przeprowadzenia badań satysfakcji użytkowników.

Ostatecznie w badaniach wzięły udział 44 biblioteki, ponieważ dwie spośród wylosowanych bibliotek wiejskich wycofały się z przedsięwzięcia (tab. 1).

Tabela 1. Biblioteki publiczne w województwie dolnośląskim wg statusu

\begin{tabular}{|c|l|c|c|}
\hline Lp. & \multicolumn{1}{|c|}{ Status } & Liczba bibliotek & $\begin{array}{c}\text { Biblioteki uczestniczące } \\
\text { w badaniach }\end{array}$ \\
\hline 1 & Biblioteki wojewódzkie & 1 & 1 \\
\hline 2 & Biblioteki miejskie & 36 & 10 \\
\hline 3 & Biblioteki miejsko-wiejskie & 55 & 15 \\
\hline 4 & Biblioteki wiejskie & 79 & 18 \\
\hline & RAZEM & 171 & 44 \\
\hline
\end{tabular}

Źródło: opracowanie własne.

\section{Przygotowanie bibliotekarzy do prowadzenia badań}

Kolejny etap pracy Zespołu polegał na opracowaniu materiałów szkoleniowych i przygotowaniu przedstawicieli bibliotek do samodzielnej realizacji badań satysfakcji w swoich bibliotekach według metody opracowanej przez Zespół. Ankieta przeprowadzona w trakcie szkolenia, diagnozująca dotychczasowe doświadczenia bibliotekarzy w zakresie prowadzenia badań satysfakcji i stosunek do badań ankietowych, wykazała, że 50\% bibliotekarzy nie uczestniczyło dotychczas w badaniach użytkowników w swojej bibliotece. W niektórych bibliotekach (30\%) nigdy nie prowadzono żadnych badań ankietowych. 70\% badanych wskazało, że najczę- 
ściej wiedzę o potrzebach i zadowoleniu ze świadczonych usług zbierano na podstawie rozmów z czytelnikami. Zapytaliśmy też bibliotekarzy, jakie czynniki mogą wpływać na niepodejmowanie badań w bibliotekach. $65 \%$ z nich wskazało, iż jest to obawa przed niechęcią użytkowników do wypełniania ankiet, 40\% nie ma przekonania o skuteczności badań. Tyle samo uznało, że nie ma wiedzy i umiejętności w zakresie prowadzenia badań satysfakcji wśród użytkowników bibliotek.

Powyższe wyniki potwierdziły trafność wybranych zagadnień szkoleniowych. Celem głównym szkolenia było przygotowanie do samodzielnego przeprowadzenie badań satysfakcji użytkowników według metody opracowanej przez Zespół ds. badania efektywności bibliotek. Ponadto duży nacisk położono na wykazanie korzyści wynikających z badań zarówno dla bibliotek jako instytucji, jak także dla użytkowników i bibliotekarzy. Omówiono znaczenie wskaźnika „Satysfakcji Użytkowników”, przedstawiono sposoby, metody oraz narzędzia umożliwiające realizację badania, metody analizy danych i zasady przygotowania raportu z badań.

Zespół założył, że każdy uczestnik po odbyciu szkolenia powinien nabyć umiejętności i wiedzę dotyczącą samodzielnej modyfikacji ankiety zgodnie ze specyfiką biblioteki, zdefiniowania badanej populacji i wyliczenia według metody doboru kwotowego próby badawczej, przygotowania materiałów promocyjnych i informacyjnych o planowanym badaniu, zebrania odpowiedniej liczby ankiet, zgodnie z liczebnością i strukturą próby, przeprowadzenia analizy uzyskanych wyników i sporządzenia raportu z badań. Ponadto powinien poznać i umieć wykorzystać wszelkie narzędzia przygotowane do badania satysfakcji, szablony arkuszy kalkulacyjnych do wyliczania próby i wprowadzania danych oraz poradnik.

Zespół uznał, że najlepszą formą szkoleniową będą webinaria. Metoda ta była już bowiem wcześniej wykorzystana w szkoleniach prowadzonych w ramach projektu ze względu na:

- eliminację kosztów podróży i zakwaterowania uczestników,

- oszczędność czasu uczestników (dojazd do miejsca spotkania),

- obniżenie kosztów przygotowania materiałów szkoleniowych (powstały tylko w wersji elektronicznej i udostępniane były za pomocą sieci).

Cykl szkoleń w postaci czterech godzinnych spotkań online odbył się w okresie od 19 stycznia do 4 kwietnia 2016 r. 
Program ujęty w cztery moduły tematyczne obejmował:

- spotkanie informacyjno-organizacyjne,

- metodologię badań,

- analizę danych 1 ,

- analizę danych 2 oraz zasady opracowania raportu z badań.

\section{Realizacja webinariów}

Webinaria realizowane były na platformie Clickmeeting. W tym celu założono wirtualny pokój oraz przygotowano formularze rejestracyjne dla uczestników. Na platformie zamieszczono prezentacje przygotowane w programie PowerPoint oraz ankiety opracowane w celach diagnostycznych i ewaluacyjnych. Przebieg szkoleń uzupełniany był prezentowaniem na żywo struktury i zawartości strony AFB, narzędzia badawczego, funkcjonalności arkuszy kalkulacyjnych opracowanych z myślą o odbiorcach szkolenia. Komunikacja uczestników z prowadzącymi oraz pomiędzy uczestnikami odbywała się za pomocą czatu tekstowego.

Po zakończeniu każdego z webinariów uczestnicy otrzymywali odsyłacz hipertekstowy do nagrania oraz zestaw materiałów prezentowanych w trakcie szkolenia. Zarchiwizowane nagrania webinariów pozwalały bibliotekarzom na asynchroniczne uczestnictwo w spotkaniach. Było to ważne dla osób, które z różnych względów nie mogły brać udziału w spotkaniach na żywo. Dodatkowo, nagrania webinariów mogły też być zastosowane jako materiały edukacyjne wykorzystane w samokształceniu. Uczestnictwo w webinariach kształtowało się średnio na poziomie 79\% (tab. 2).

Tabela 2. Liczba uczestników poszczególnych webinariów

\begin{tabular}{|l|c|c|}
\hline \multicolumn{1}{|c|}{ Data webinarium } & Liczba uczestników & Udział procentowy \\
\hline 19.01 .2016 & 36 & $82 \%$ \\
\hline 28.01 .2016 & 37 & $84 \%$ \\
\hline 4.02 .2016 & 38 & $86 \%$ \\
\hline 4.04 .2016 & 28 & $64 \%$ \\
\hline
\end{tabular}

Źródło: opracowanie własne. 
Rezultaty szkolenia kontrolowano w trakcie webinariów. Stałym elementem były bowiem pytania ankietowe, które pomagały poznać potrzeby uczestników, ich wiedzę i umiejętności. Wyniki ankiet były na bieżąco prezentowane i analizowane przez prowadzących. Uczestników pytano o:

- dotychczasowe doświadczenia w zakresie prowadzenia badań użytkowników bibliotek,

- nastawienie do tego typu badań,

- znajomość pojęć z zakresu metodologii badań społecznych,

- planowane sposoby dystrybucji ankiety,

- znajomość arkuszy kalkulacyjnych,

- przebieg badań (czy zostało zrealizowane, czy zebrano wymaganą liczbę ankiet i jakie metody dystrybucji ankiet wykorzystano).

W trakcie ostatniego webinarium uczestnicy dokonali ewaluacji wszystkich spotkań. Szczególnie wysoko ocenili:

- przejrzystość przekazywanych treści, przydatność materiałów pomocniczych,

- formę szkolenia, którą uznali za bardzo wygodną,

- kompetencje szkolących, sprawność prowadzenia zajęć, jasny i zrozumiały przekaz.

Uczestnicy webinariów uzyskali informacje i nabyli umiejętności pozwalające na przeprowadzenie badań według zaproponowanej metody oraz wypełnianie przygotowanych przez Zespół szablonów arkuszy kalkulacyjnych do wyliczania próby i analizy danych. Otrzymali także wsparcie merytoryczne w rozwiązywaniu problemów pojawiających się w trakcie badań.

\section{Organizacja badań}

Zgodnie z założeniami projektu AFB badanie satysfakcji powinno być przeprowadzone w bibliotece głównej i filiach. Odpowiedzialność za badania w sieci lokalnej ponosił bibliotekarz - pracownik biblioteki głównej, który uczestniczył w szkoleniu i pełnił funkcję koordynatora badań. Jego zadaniem było zebranie z poszczególnych jednostek danych dotyczących wielkości i struktury populacji do wyliczenia próby badawczej, modyfikacja ankiety, nadzór nad zbieraniem ankiet w celu zachowania 
właściwej struktury w uzyskanej próbie kwotowej (analiza kwotowa), wprowadzanie danych $\mathrm{z}$ ankiet do szablonu arkusza kalkulacyjnego, ich analiza i przygotowanie raportu z badań.

Za poprawny przebieg badań w województwie dolnośląskim odpowiedzialny był trzyosobowy Zespół, który przeprowadził szkolenie i kontrolował realizowane przez bibliotekarzy zadania: wyliczanie próby, analizę kwotową, poprawność danych w arkuszach kalkulacyjnych i raportów z badań. Ponadto pracownik biblioteki wojewódzkiej we Wrocławiu był odpowiedzialny za komunikację między Zespołem i bibliotekarzami realizującymi badania.

Biblioteki uczestniczące w projekcie nie ponosiły żadnych kosztów finansowych. Ankiety potrzebne do badań zostały wydrukowane i przesłane do bibliotek przez SBP.

\section{Przebieg badań}

Termin realizacji badań został wyznaczony na 22.02.-31.03.2016 r. Dla części bibliotek termin ten okazał się jednak za krótki na zebranie wskazanej liczby ankiet. 23 instytucje wydłużyły czas dystrybucji ankiet maksymalnie do 1,5 miesiąca. Pierwszym zadaniem, jakie biblioteki miały wykonać, była modyfikacja ankiety zgodnie ze swoimi potrzebami w zakresie świadczenia usług. Modyfikacja polegała na usunięciu z pytania dotyczącego oceny poszczególnych obszarów działania biblioteki tych elementów, które nie występują w danej placówce. Zmian w kwestionariuszu dokonało 30 bibliotek, pozostałe 14 instytucji posiadało pełen wskazany pakiet usług i nie wprowadziły żadnych zmian w narzędziu badawczym. Najczęściej usuwanymi punktami były te dotyczące oceny: zbiorów elektronicznych (55\% bibliotek), zbiorów audiowizualnych (48\%) oraz witryny internetowej biblioteki (32\%).

Kolejne zadanie polegało na zdefiniowaniu badanej populacji, określeniu jej liczebności i struktury wg zmiennej „wiek”. W przypadku sieci każda filia przesyłała dane o swoich użytkownikach do biblioteki głównej, która nadesłane dane sumowała i wprowadzała do arkusza kalkulacyjnego, umożliwiającego wyliczenie wielkości próby badawczej oraz określenie jej struktury według zmiennej „wiek”. 0 wielkości próby badawczej decydowała wielkość obsługiwanej populacji, zdefiniowanej jako liczba 
aktywnych użytkowników zapisanych do biblioteki, to znaczy takich, którzy w ciągu minionego roku wypożyczyli, zwrócili lub prolongowali co najmniej 1 książkę. Próba badawcza wyliczana była według wytycznych:

- populacja mniejsza niż 200: należy objąć badaniem wszystkich użytkowników,

- populacja w przedziale 201-500: liczebność próby to $60 \%$ populacji,

- populacja w przedziale 501-2000: liczebność próby to 30\% populacji,

- populacja większa niż 2000: liczba ankiet 600.

Tabela 3. Liczba bibliotek wg wielkości populacji badanej

\begin{tabular}{|c|c|c|c|c|c|c|}
\hline \multirow[b]{2}{*}{ Lp. } & \multirow{2}{*}{$\begin{array}{l}\text { Wielkość } \\
\text { populacji }\end{array}$} & \multicolumn{4}{|c|}{ Тур } & \multirow[b]{2}{*}{ Suma } \\
\hline & & wojewódzka & miejska & $\begin{array}{l}\text { miejsko- } \\
\text { wiejska }\end{array}$ & wiejska & \\
\hline 1 & $<200$ & & & & & 0 \\
\hline 2 & $201-500$ & & 1 & 1 & 4 & 6 \\
\hline 3 & 501-2000 & & 1 & 9 & 14 & 24 \\
\hline \multirow[t]{2}{*}{4} & $>2000$ & 1 & 8 & 5 & & 14 \\
\hline & Suma & 1 & 10 & 15 & 18 & 44 \\
\hline
\end{tabular}

Źródło: opracowanie własne.

Pod względem wielkości populacji najliczniejszą grupę (24 placówki) stanowiły biblioteki liczące 501-2000 użytkowników. W badaniu nie uczestniczyła żadna biblioteka o populacji mniejszej niż 200 użytkowników. W grupie bibliotek miejskich najwięcej było bibliotek obsługujących powyżej 2000 użytkowników. W grupach bibliotek miejsko-wiejskich i wiejskich przeważały biblioteki średnie, o populacjach od 501 do 2000 użytkowników.

Wielkość prób badawczej w poszczególnych bibliotekach mieściła się w zakresie 157-600 respondentów. Zdecydowana większość bibliotek zebrała wymaganą liczbę ankiet (tab. 4). Jedna z instytucji w trakcie dystrybucji ankiet zrezygnowała z dalszej realizacji badań, ponieważ w wyznaczonym terminie zebrała tylko $22 \%$ wymaganych ankiet. 
Tabela 4. Poziom realizacji próby badawczej

\begin{tabular}{|c|c|c|}
\hline Poziom realizacji próby & Liczba bibliotek & $\%$ \\
\hline $100 \%-90 \%$ & 35 & $79,55 \%$ \\
$89 \%-70 \%$ & 4 & $9,09 \%$ \\
$69 \%-50 \%$ & 2 & $4,55 \%$ \\
$49 \%-30 \%$ & 2 & $4,55 \%$ \\
$29 \%-0 \%$ & 1 & $2,27 \%$ \\
Suma & 44 & $100,00 \%$ \\
\hline
\end{tabular}

Źródło: opracowanie własne.

Przed rozpoczęciem badań biblioteki miały przeprowadzić akcję promocyjną i informacyjną, aby zapoznać użytkowników z planowanymi działaniami. Około $50 \%$ bibliotek przygotowało materiały informacyjne w postaci plakatów i ulotek, $40 \%$ bibliotek ustnie poinformowało swoich użytkowników o badaniu, a 35\% umieściło informacje na stronach WWW i na portalach społecznościowych. Tylko 10\% bibliotek zamieściło komunikat w prasie lokalnej.

Głównym sposobem dystrybucji ankiet było wyłożenie ich w miejscach najczęściej odwiedzanych przez użytkowników: wypożyczalniach i czytelniach. Jedynie 30\% bibliotek wykorzystało dodatkowe kanały dystrybucji: rozdawanie ankiet podczas szkoleń i wydarzeń kulturalnych, udostępnienie ich w Internecie lub wysłanie ankiet do użytkowników za pośrednictwem maila. To niewielkie wykorzystanie innych kanałów dystrybucji być może wpłynęło na konieczność przedłużenia badań ze względu na zebranie zbyt małej liczby ankiet w zaplanowanym terminie.

Dane zebrane $\mathrm{z}$ ankiet zostały wprowadzone do przygotowanych szablonów arkuszy kalkulacyjnych, które umożliwiają ich zliczenie, prezentację wyników zbiorczych, wyznaczenie globalnego wskaźnika „Satysfakcji Użytkowników" i wskaźników szczegółowych. Ponadto ułatwiają graficzną prezentację danych oraz dokonywanie bardziej złożonych analiz na podstawie tabel krzyżowych.

Ostatnim etapem badań było przygotowanie raportu. Na podstawie schematu sprawozdania zaproponowanego przez Zespół bibliotekarze opracowali raporty końcowe ze swoich badań. Choć realizacja tego dzia- 
łania okazała się najtrudniejszym punktem planu, wszystkie biblioteki wywiązały się z tego zadania.

Dane z badań uzyskane od bibliotekarzy zostały scalone w zbiorcze arkusze kalkulacyjne według określonych kluczy: typu biblioteki (biblioteki miejskie, miejsko-wiejskie oraz wiejskie) oraz liczby obsługiwanej populacji (biblioteki małe <500 użytkowników, średnie od 501 do 2000 użytkowników oraz duże >2000 użytkowników). Zestawienia nie dają możliwości powiązania danych z poszczególnymi bibliotekami. Mają one służyć zbiorczym analizom wyników badań zaplanowanych na rok 2017. Analizy te opierać się będą na poszukiwaniu elementów różnicujących grupy bibliotek oraz wyjaśnianiu przyczyn tych różnic. Podjęta zostanie próba powiązania uzyskanych globalnych i szczegółowych wskaźników „Satysfakcji Użytkowników” z wybranymi wskaźnikami funkcjonalności w danej grupie bibliotek. Poza tym Zespół zaplanował opracowanie profili poszczególnych grup bibliotek i użytkowników korzystających z ich usług.

\section{Podsumowanie}

Badania satysfakcji użytkowników z wykorzystaniem jednolitego narzędzia i wspólnej procedury badawczej, przeprowadzone w województwie dolnośląskim, stanowią pierwsze tego rodzaju przedsięwzięcie zorganizowane równolegle w grupie kilkudziesięciu bibliotek.

Na podstawie opinii bibliotekarzy realizujących badania oraz obserwacji Zespołu ds. badania efektywności bibliotek można stwierdzić, że zarówno ankieta, jak i przygotowana metoda badania satysfakcji użytkowników zostały przyjęte i ocenione pozytywnie.

Korzyści płynące z tego działania wydają się obopólne. Bibliotekarze mieli możliwość zarówno poznania metod badania satysfakcji użytkowników, przeprowadzenia (niektórzy po raz pierwszy) tego rodzaju badań, jak i oceny efektywności funkcjonowania swoich bibliotek. Ponadto, dzięki tej współpracy powstały nowe narzędzia mające ułatwić realizację badań - formularz do wyliczania próby i przeprowadzenia analizy kwotowej.

Zespołowi SBP badania pozwoliły z kolei na sprawdzenie, w większej grupie bibliotek, proponowanej metodyki i poznanie najczęściej występujących problemów, które pojawiły się w trakcie ich realizacji. 
Bibliotekarze wskazali, że niektóre sformułowania w ankiecie wymagają doprecyzowania, a kilka punktów w dostępnych instrukcjach uzupełnienia. Ze względu na niechęć użytkowników do wypełniania ankiet barierą $\mathrm{w}$ badaniach okazało się ich zbieranie, co niekorzystnie wpływało na realizację próby badawczej. Niewielka grupa bibliotekarzy miała problemy z użytkowaniem arkuszy kalkulacyjnych służących do wyliczania próby i rejestracji danych $\mathrm{z}$ ankiet oraz ich analizą.

W opinii bibliotekarzy największą trudnością w realizacji zadania był duży nakład pracy i czasu niezbędnego do przeprowadzenia badań. Może to sprawić, że w przyszłości realizacja całego przedsięwzięcia w małych placówkach, zwłaszcza jednoosobowych, będzie dosyć trudna.

Z perspektywy osób koordynujących badania budujące jest, że coraz więcej bibliotekarzy ma świadomość korzyści płynących z realizacji badań satysfakcji zarówno dla użytkowników, władz, jak i samych pracowników biblioteki.

Projekt realizowany w bibliotekach województwa dolnośląskiego może przyczynić się do popularyzacji idei badania satysfakcji użytkowników według jednolitej metodyk w bibliotekach różnego typu i wyznaczania wskaźników „Satysfakcji Użytkowników” będących integralną częścią systemu analizy efektywności bibliotek.

\section{Bibliografia}

Kędzierska Edyta, Sobielga Jolanta, Zawałkiewicz Aldona, Nowa jakość w badaniach użytkowników bibliotek, „Bibliotekarz” 2015, nr 1, s. 12-15.

Kędzierska Edyta, Zawałkiewicz Aldona, Jak przeprowadzić badania satysfakcji użytkowników biblioteki? Poradnik dla bibliotekarzy [online]. Portal afb.sbp. pl [dostęp 31 marca 2017]. Dostępny w World Wide Web: http://pliki.sbp. pl/afb/jak-przeprowadzic-badania-satysfakcji.pdf.

PN-ISO 11620:2012 Informacja i dokumentacja - Wskaźniki funkcjonalności bibliotek.

\section{User Satisfaction Survey in Public Libraries of Lower Silesia Voivodeship}

ABSTRACT: A user satisfaction survey was conducted in 44 public libraries in Lower Silesian Voivodeship (a provincial library, urban libraries, urban-rural 
libraries and rural libraries), with the use of a uniform questionnaire and an examination procedure. The survey was organized and coordinated by the members of the Polish Librarians' Association's Library Effectiveness Investigation Team. The survey aimed at establishing the "User Satisfaction" index which, along with other functionality indices developed due to the project "The Performance Analysis for Polish Libraries", is a system of complex measurement of library effectiveness.

KEYWORDS: "User Satisfaction" index, effectiveness survey, library user research, public library. 